\title{
Effects of Dietary Lysine on Broiler Performance and Carcass Yield - Meta-Analysis
}

http://dx.doi.org/10.1590/1516-635x1604425-430

\section{Euthor(s) \\ Mendes AS \\ Api II \\ Silva L" \\ Silva RTL" \\ Sausen L" \\ Menezes LFG \\ Morello GM"II \\ Carvalho $\mathrm{EH}^{\prime \prime}$}

Agronomy Department. Federal Technological University of Paraná, Dois Vizinhos, PR, Brazil. E-mail: angelica@utfpr. edu.br; luismenezes@utfpr.edu.br.

" Graduate Research Assistants at PPGZO Federal Technological University of Paraná Campus Dois Vizinhos. E-mail: ivandroapi@ hotmail.com; leandrods94@hotmail.com; rita.biologia@hotmail.com; Isausenvet@ yahoo.com.br

III Graduate Research Assistant at the Animal Sciences Department, Purdue University, West Lafayette, IN, 47907, U.S.A. E-mail: gabymm@gmail.com

\begin{abstract}
There has been a great evolution and improvement in the nutrition of poultry and lysine has been used the reference amino acid to increase animal protein deposition. Therefore, a meta-analysis was performed with the objective of studying the effect of different dietary lysine levels on the performance and carcass yield of broiler chickens. In total, 21 studies published in Brazil since 1999 were included. Bird performance considered daily weight gain (178 observations) and feed conversion ratio (188 observations) results. Carcass quality was evaluated relative to carcass yield (24 observations), abdominal fat (24 observations) and breast meat yield (30 observations). Data were checked for normality and were submitted to analysis of variance. Weight gain and carcass yield increased with the addition of $1.05 \%$ of lysine to the diet, whereas feed conversion ratio and abdominal fat were reduced as dietary lysine concentration increased. The results, therefore, indicate that lysine is essential in bird nutrition and significantly affects bird performance and carcass yield.
\end{abstract}

\section{INTRODUCTION}

The development of production practices that increase productivity within a short period of time has been is essential to supply the increasing demand for animal protein by the growing global population. The poultry industry is one of the most efficient sectros of the meat industry in terms of converting plants into protein products for human consumption (Moro et al., 2005).

The nutritional requirements of meat-producing animals needs to be reguarly updated to allow for better production performance of modern broilers as they ardue to their continuous genetic improvement. Changes in broiler growth rate and carcass yield have been associated with the supply of amino acids, such as lysine, which is a reference amino acid to increase animal protein deposition (Trindade Neto et al., 2010).

Broilers require more dietary lysine during early growth stages, lysine dietary level depends on the parameters measured, such as weight gain, abdominal fat, and feed conversion ratio (Campestrini et al., 2010). The balance of dietary amino acids is also important, because inadequate ratios among amino acids may negatively affect bird performance, and cause locomotion, feathering, and immunity problems (Kidd \& Fancher, 2001).

There is a substantial amount of information in the literature on the effects of dietary lysine levels on the development and performance of broiler chickens (Rama et al., 2011; Salehifar et al., 2012; Mateos et al., 2013). Therefore, meta-analysis may provide useful and thorough information on how different dietary lysine levels of lysine may impact poultry production (Bucher et al., 2012; Kerr et al., 2013). 
Meta-analysis was originally introduced in psychology and medicine and has become increasingly popular in animal science, and applied to different species such as poultry, sheep, cattle, and pigs (Sauer et al., 2008). Meta-analysis is a statistical technique that consists of combining the results of several studies in one single analysis to obtain broadly valid inferences (Van Houwelingen et al., 2002). This study, therefore, aimed at performing a meta-analysis to evaluate the effects of dietary lysine levels on the performance and carcass yield of broiler chickens.

\section{MATERIAL AND METHODS}

This study was conducted at the Federal Technological University of Paraná, Dois Vizinhos campus, Brazil (UTFPR-DV). A total of 47 scientific papers on the effects of dietary lysine levels on poultry performance were found and a total of 21 papers were selected to perform the meta-analysis. The scientific papers used are listed in Table 1.

The effects of dietary lysine levels on performance parameters evaluated, including weight gain (178 observations) and feed conversion ratio (188 observations), and on carcass quality, including carcass yield (24 observations), abdominal fat (24 observations) and breast meat yield (30 observations), were evaluated.
Data obtained from the selected studies (Table 1) were first organized in Microsoft Excel ${ }^{\circledR}$ spreadsheets. Bird age was designated within ranges, as illustrated in Table 1. The dietary lysine levels evaluated among the selected studies were further divided into five categories within the ranges of $0.8-0.9 ; 0.91-1.0$; $1.01-1.1 ; 1.11-1.2 ; 1.21-1.3 \%$.

The following tests of normality were applied: Kolmogorov-Smirnov, Cramer-von Mises, AndersonDarling, Kuiper, Watson, Lilliefors and Shapiro-Wilk test, using the software Assistat (Silva \& Azevedo, 2002). The data were submitted to analysis of variance and estimates of regression equations to the third grade were obtained using the statistical software SAS (2001). Lysine concentration was regressed as linear functions of weight gain, carcass yield, breast meat yield, abdominal fat and feed conversion ratio. The addition of quadratic and cubic terms was also tested in the regressions.

\section{RESULTS AND DISCUSSION}

Table 2 presents the statistical results of the analysis of variance of the regression equations, including the degrees of freedom (DF), sum of squares (SS), mean square (MS), $p$-value ( $p$ ) for the overall quadratic model and coefficient of variation (CV) for each of the dependent variables, including weight gain (WG), feed conversion ratio $(\mathrm{FC})$, breast meat yield $(\mathrm{BM})$, carcass yield (CY) and abdominal fat (AF).

Table 1 - Scientific papers used in the meta-analysis of dietary lysine levels and their effects in poultry performance.

\begin{tabular}{lccc}
\hline Author & Number of Birds Studied & Bird Age [days] & Dietary Lysine Levels Studied [\%] \\
\hline Conhalato et al. (1999) & 450 & $22-42$ & $0.88 ; 0.94 ; 1.00 ; 1.06 ; 1.12$ \\
\hline Barbosa et al. (2000) A & 1920 & $22-40$ & $0.8 ; 0.86 ; 0.92 ; 0.98 ; 1.04 ; 1.10$ \\
\hline Barbosa et al. (2000) B & 1920 & $15-40$ & $0.83 ; 0.89 ; 0.95 ; 1.01 ; 1.07 .1 .13$ \\
\hline Barbosa et al. (2000) C & 1920 & $01-21$ & $1.00 ; 1.06 ; 1.12 ; 1.18 ; 1.24 ; 1.30$ \\
\hline Bellaver et al. (2002) & 2808 & $01-21$ & $0.92 ; 1.02 ; 1.12 ; 1.22$ \\
\hline Costa et al. (2001) A & 1440 & $01-21$ & $1.03 ; 1.09 ; 1.15 ; 1.21 ; 1.27 ; 1.33$ \\
\hline Costa et al. (2001) B & 1440 & $22-40$ & $0.92 ; 0.98 ; 1.04 ; 1.10 ; 1.16 ; 1.22$ \\
\hline Barbosa et al. (2001) & 972 & $42-56$ & $0.94 ; 1.04 ; 1.14$ \\
\hline Borges et al. (2002) & 400 & $01-21$ & $1.04 ; 1.10 ; 1.16 ; 1.22 ; 1.28$ \\
\hline Lana et al. (2005) & 378 & $22-42$ & $0.78 ; 0.84 ; 0.89 ; 0.96 ; 1.02$ \\
\hline Amarante Jr. et al. (2005) & 1800 & $22-42$ & $0.94 ; 1.02 ; 1.09 ; 1.18 ; 1.26 ; 1.34$ \\
\hline Costa et al. (2005) & 900 & $22-42$ & $0.94 ; 1.02 ; 1.09 ; 1.18 ; 1.26 ; 1.34$ \\
\hline Costa et al. (2006) A & 900 & $22-42$ & $0.94 ; 1.02 ; 1.10 ; 1.18 ; 1.26 ; 1.34$ \\
\hline Costa et al. (2006) B & 900 & $43-49$ & $0.85 ; 0.93 ; 1.01 ; 1.09 ; 1.17 ; 1.25$ \\
\hline Toledo et al. (2007) & 1050 & $1-11$ & $1.12 ; 1.17 ; 1.221 .27 ; 1.35$ \\
\hline Rodrigues et al. (2008) & 1200 & $22-42$ & $1.00 ; 1.09 ; 1.17 ; 1.26 ; 1.34$ \\
\hline Goulart et al. (2008) & 780 & $01-42$ & $1.10 ; 1.16 ; 1.22 ; 1.28 ; 1.34 ; 1.40$ \\
\hline Trindade Neto et al. (2009) & 203 & $37-49$ & $0.90 ; 0.95 ; 1.00 ; 1.05 ; 1.10$ \\
\hline Trindade Neto et al. (2010) & 180 & $22-42$ & $0.84 ; 0.87 ; 0.99 ; 1.02 ; 1.03$ \\
\hline Siqueira et al. (2011) & 600 & $22-35$ & $0.79 ; 0.88 ; 0.96 ; 1.04 ; 1.13$ \\
\hline Trindade Neto et al. (2011) & 210 & $23-36$ & $0.95 ; 1.00 ; 1.05 ; 1.10 ; 1.15$ \\
\hline
\end{tabular}


Table 2 - Analysis of Variance Results.

\begin{tabular}{lccccc}
\hline & DF & SS & MS & p & CV \\
\hline WG & 2 & $1,348.65$ & 674.32 & 0.0216 & 15.90 \\
\hline FC & 2 & 337.86 & 168.931 & 0.4808 & 15.18 \\
\hline BM & 2 & $8,104.32$ & $4,052.16$ & 0.0006 & 0.55 \\
\hline CY & 2 & $1,375.22$ & 687.61 & 0.0060 & 0.18 \\
\hline AF & 2 & 0.15 & 0.08 & 0.1684 & 3.42 \\
\hline
\end{tabular}

The coefficient of variation results presented in Table 2 were consistent with literature: Silva et al. (2008), de 6.63\%; Marcondes et al. (2008), 11.63\% and Canesin et al. (2006), 7.96\%. The addition of the quadratic term was significant for weight gain (WG) as a function of lysine concentration, as illustrated in Figure 1. The highest weight gain values were obtained with lysine concentration of $1.05 \%$ and the second order relationship between weight gain ( $\mathrm{g}$ ) and lysine concentration (\%) is given by the following equation $\left(R^{2}=0.05\right)$ :

$$
\mathrm{GP}=-3248.39+8276.57 \text { * Lysine Level }-3981.09
$$

* Lysine Level $^{2}$

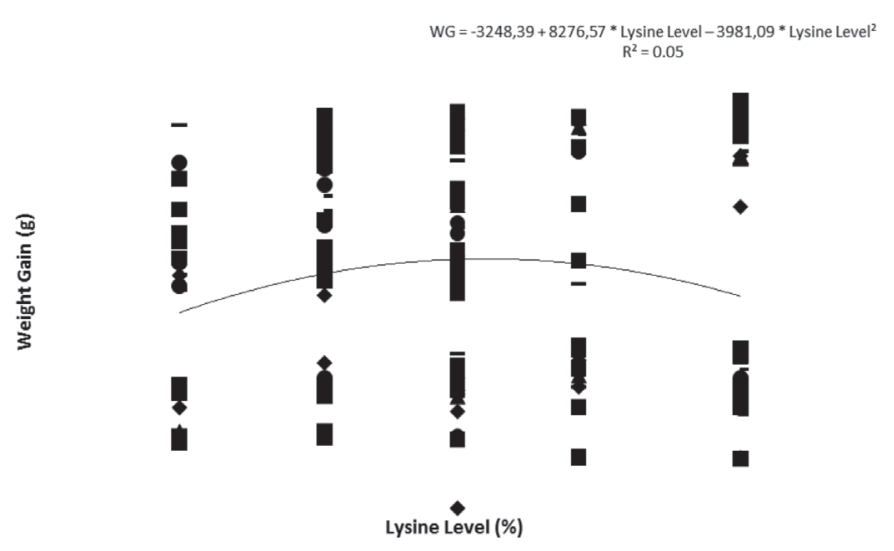

Figure 1 - Broiler weigh gain (g) as a second order function of lysine level (\%).

Goulart et al. (2008) evaluated lysine requirements of broiler chickens during three rearing phases (pre-starter, 1-7, starter, 8-21 and grower, 2242 days of age). The authors also found a second order relationship between weight gain and lysine concentration, as well as between feed conversion ratio and lysine concentration $(p<0.01)$. The highest weight gain $(117.6 \mathrm{~g} / \mathrm{bird})$ and the best feed conversion ratio $(1.09 \mathrm{~kg} / \mathrm{kg})$ in the pre-starter phase were obtained at lysine concentrations of $1.286 \%$ and $1.239 \%$, respectively. The authors found that, before reaching the best performance at the reported lysine levels, the diet was either deficient in lysine or unbalanced relative to the other dietary amino acids. Above the optimal lysine levels, however, bird performance did not improve with increasing lysine levels, and lysine was excreted.
Amino acids in excess are catabolized and excreted as uric acid (Leclercq, 1998). The metabolic cost to incorporate an amino acid to a protein chain is of approximately ATP molecules, whereas the cost to excrete an amino acid is 6 to 18 ATP molecules, depending on the amount of nitrogen present in the amino acid. Moreover, the excretion of excessive dietary amino acids will expends energy that could instead be utilized for tissue deposition, and therefore it is very costly for the birds (Costa et al., 2001).

High dietary lysine levels may change the function and the requirements of other amino acids, such as arginine, which in turn changes the requirements of methionine, affecting bird development and performance (Chamruspollert et al., 2002).

Namazu et al. (2008) also found a quadratic relationship between weight gain and dietary lysine levels. However, it was found that feed intake has a first order relationship with lysine levels. Sklan \& Noy (2004) evaluated starter male and female broiler chickens and found that that weight gain improved with $1.05 \%$ of dietary lysine, as determined in the present study, whereas the best feed conversion ratio was obtained with $1.03 \%$ of lysine. Trindade Neto et al. (2010) recommended a minimum of $1.002 \%$ of digestible lysine for high-yield cuts of male broilers.

Toledo et al. (2007) reported that dietary lysine level should not be lower than $1.20 \%$ for male Ross broilers between 1 and 11 days of age reared under low immune challenge conditions. Kidd \& Fancher (2001) proposed an optimal lysine level of $1.22 \%$ for starter broilers to obtain high weight gain and carcass yield. Barboza et al. (2000) found a quadratic relationship between both weight gain and feed conversion ratio and dietary lysine levels. The authors reported 1,265.4 $\mathrm{g}$ weight gain in male Ross chickens and 1,269.2 in Hubbard male chickens with lysine concentrations of $0.98 \%$ and $0.92 \%$, respectively. Ross and Hubbard female chickens presented weight gains of $1,047.0 \mathrm{~g}$ and $1,017.4 \mathrm{~g}$, respectively, for the same lysine levels. Rostagno et al. (2005) found a second order relationship $(p<0.05)$ between weight gain and lysine. The authors suggested a requirement of $1.044 \%$ of dietary lysine for broiler chickens. Their recommendation is higher than the level suggested by Barboza et al. (2000) of $0.90 \%$.

Feed conversion ratio presented a second order relationship with lysine levels, as illustrated in Figure 2. Feed conversion ratio decreased as lysine levels increased and this relationship is shown by the following equation: 
$F C R=4.10-2.77$ * Lysine Level +0.78 * Lysine Level $^{2}\left(R^{2}=0.23\right)$

Eq. (2)

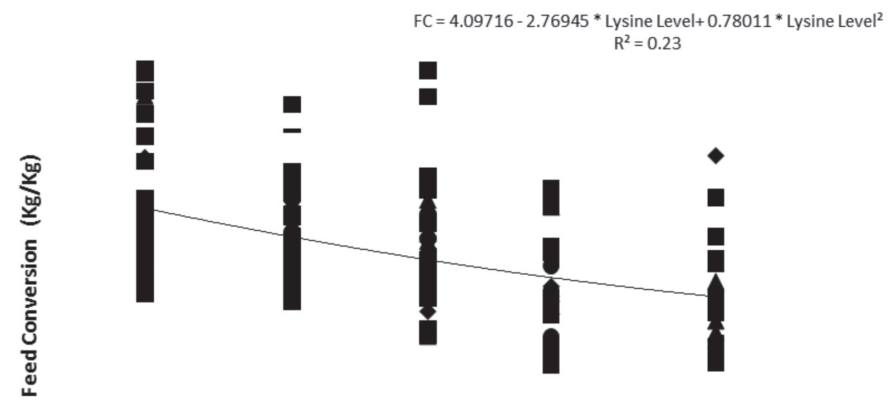

Lysine Level (\%)

Figure 2 - Broiler feed conversion ratio as a second order function of lysine levels.

Siqueira et al. (2011) found an exponential relationship between feed conversion ratio and dietary lysine levels for broiler chickens during the grower and finisher phases, as described by the following equation:

$\mathrm{FCR}=1.84-0.22 *\left(e^{-6.44 *(\text { lysine level }-0.75)}\right)$.

Trindade Neto et al. (2009), however, found a first order relationship between feed conversion ratio and lysine levels, as described by the equation:

$F C R=3.16-0.87$ * lysine levels

Those authors stressed that lysine levels should not be lower than $1.10 \%$ or a total of 29.6 grams during the finisher phase (35 to 47 days).

Costa et al. (2006) also reported that feed conversion ratio improved with increasing lysine levels, as described by the first order $(p<0.01)$ equation:

$F C=1.57+0.29$ lysine levels $\left(R^{2}=0.75\right) \quad$ eq. (5)

Nascimento (2003) found that increasing dietary lysine levels promoted higher muscle deposition and weight gain, and reduced abdominal fat, leading to better feed conversion ratio.

Siqueira et al. (2007) reported $1.64 \mathrm{~kg} / \mathrm{kg}$ feed conversion ratio in broiler chickens fed $1.085 \%$ lysine, which is close to the results of the present study and to the recommendation of Rostagno et al. (2005) of $1.045 \%$ lysine for broiler chickens. Accordingly, Lana et al. (2005) reported optimal feed conversion ratio with $1.075 \%$ dietary lysine level fed 22 - to 42-day-old broiler chickens reared in zone of least thermoregulatory effort $\left(23.8^{\circ} \mathrm{C}\right)$.

Carcass yield has been shown to increase with increasing dietary lysine levels (Almeida et al., 2002). Accordingly, carcass yield and breast meat yield increased with lysine levels at a second order relationship, as shown in Figures 3 and 4 and described by the following equations:
$C Y=27.87+76.45$ * lysine level -37.30 * lysine level2 $\left(R^{2}=0.97\right)$

Eq. (6)

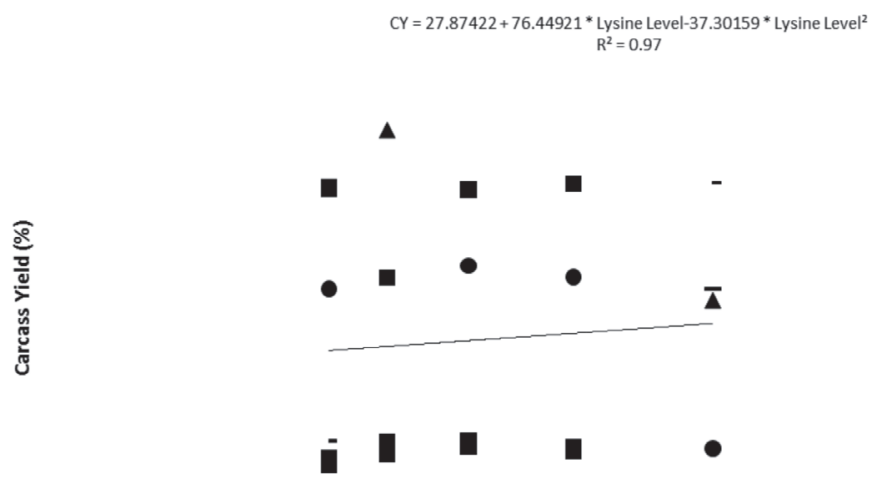

Lysine Levels (\%)

Figure 3 - Broiler carcass yield as a second order function of lysine level.

$\mathrm{BMY}=-63.76+165.36$ * lysine level -79.81 * lysine level ${ }^{2}\left(R^{2}=0.99\right)$

Eq. (7)

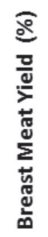

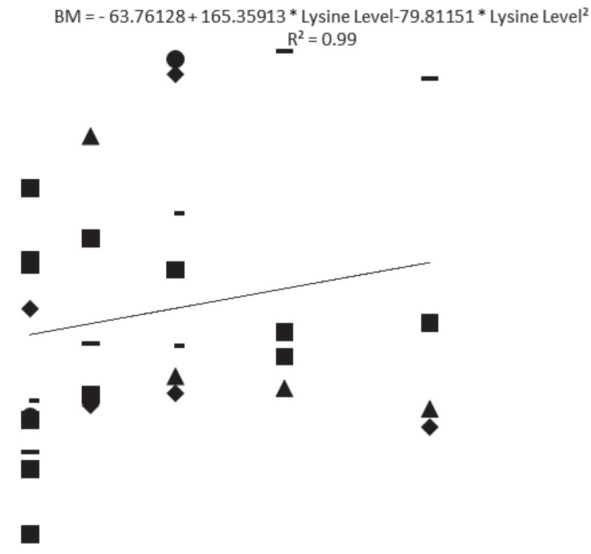

Lysine Level (\%)

Figure 4 - Broiler breast meat yield as a second order function of lysine level.

Valério et al. (2003) and Siqueira et al. (2007) did not find any significant $(p \geq 0.05)$ effect of dietary lysine levels on carcass yield. Pavan et al. (2003) studied broiler feeds based on corn and soybean meal containing lysine levels of $1.18,1.24$, and $1.30 \%$ in pre-starter diets; $1.10,1.16$, and $1.22 \%$ in starter diets; $1.0,1.06$, and $1.12 \%$ in grower diets; and 0.85 , 0.91 , and $0.97 \%$ in finisher diets, and did not find any relationship between lysine levels and breast meat yield.

Almeida et al. (2002) found that increasing dietary lysine levels promoted higher breast meat yield $(p \leq 0.05)$, especially in 49-day-old female broilers. Goulart et al. (2008) obtained a quadratic relationship between dietary lysine levels and breast meat weight 
$(p \leq 0.05)$, suggesting a dietary level of $1.008 \%$ lysine to achieve maximum breast meat weight. Ojano-Dirain \& Waldroup (2002) verified that increasing dietary lysine levels from $1.03 \%$ to $1.12 \%$ increased breast meat yield and reduced abdominal fat yield.

Lysine level had a quadratic relationship with abdominal fat $(p \leq 0.01)$, as described by the equation:

$A F=10.46-15.04$ * lysine level +6.94 * lysine level ${ }^{2}\left(R^{2}=0.88\right)$

The lowest abdominal fat levels were obtained with $1.28 \%$ dietary lysine (Figure 5).

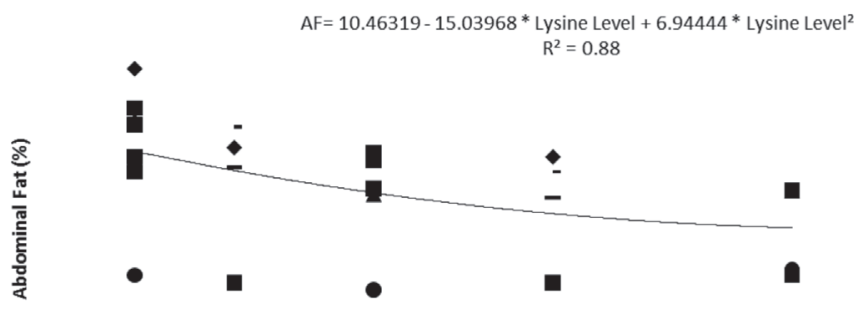

Lysine Level (\%)

Figure $\mathbf{5}$ - Relationship between abdominal fat (\%) and dietary lysine levels (\%) in broiler chickens.

The obtained abdominal fat results are consistent with the findings of Barboza et al. (2000) and Costa et al. (2006). Almeida et al. (2002) found that increasing dietary lysine levels up to $1.00 \%$ allow for the reduction of abdominal fat in broilers. Accordingly, Borges et al. (2002) reported a quadratic reduction in abdominal fat as lysine levels were increased up to $1.11 \%$, as described by the equation:

$\mathrm{AF}=1.92 *$ lysine level $^{2}+4.27$ *lysine level +1.01 $\left(R^{2}=0.91\right)$

Costa et al. (2001), on the other hand, that the relationship between lysine levels and abdominal fat was linear.

\section{CONCLUSIONS}

Dietary lysine levels of approximately $1.05 \%$ resulted in higher weight gain in broilers. High dietary lysine levels promoted better feed conversion ratio, greater breast meat yield, and reduced abdominal fat yield. Therefore, bird performance and carcass yield are strongly affected by dietary lysine concentration.

\section{REFERENCES}

Almeida ICL, Mendes AA, Oliveira EG, Garcia RG, Garcia, EA. Efeito de dois níveis de lisina e do sexo sobre o rendimento e qualidade da carne de peito de frangos de corte. Revista Brasileira de Zootecnia 2002;31(4):1744-1752.
Amarante Jr VS, Costa FGP, Barros LR. Níveis de lisina para frangos de corte nos períodos de 22 a 42 e de 43 a 49 dias de idade, mantendo a relação metionina + cistina. Revista Brasileira de Zootecnia 2005; 34:1188-1194.

Barbosa MJB, Junqueira OM, Andreotti MO, Cancherini LC, Araújo LF. Desempenho e rendimento de carcaça de frangos de corte submetidos a diferentes níveis de treonina e lisina, na fase final de criação. Revista Brasileira de Zootecnia 2001; 30(5):1476-1480

Barbosa WA, Rostagno HS, Teixeira ALF, Rodrigues PB. Níveis de lisina para frangos de corte de 22 a 40 e 42 a 48 dias de idade. Revista Brasileira de Zootecnia 2000;29(4):1091-1097.

Bellaver C, Guidoni AL, Brum PAR, Rosa PS. Estimativas das exigências de lisina e de energia metabolizável em frangos de corte de 1 a 21 dias de idade, utilizando-se uma variável multivariada canônica. Revista Brasileira de Zootecnia 2002; 31(1): 71-78.

Borges AF, Oliveira RFM, Donzele, JL, Albino LFT, Orlando UAD, Ferreira RA. Exigência de lisina para pintos de corte machos mantidos em ambiente com alta temperatura. Revista Brasileira de Zootecnia 2002;31(1):394401.

Bucher O, Rajić A, Waddell LA, Greig J, McEwen SA. Do any spray or dip treatments, applied on broiler chicken carcasses or carcass parts, reduce Salmonella spp. prevalence and/or concentration during primary processing? A systematic review-meta-analysis. Food Control 2012;27(2):351-361.

Campestrini E, Barbosa MJB, Nunes RV. Níveis de lisina digestível com dois balanços eletrolíticos para pintos de corte na fase inicial, de 1 a 21 dias de idade. Revista Brasileira de Zootecnia 2010;39(1):151-157.

Chamruspollert M, Pesti GM, Bakalli RI. Dietary interrelationships among arginine, methionine, and lysine inyoung broiler chicks. British Journal of Nutrition 2002; 88(6):655-660

Conhalato GS, Donzele JL, Albino LFT. Níveis de lisina digestível para frangos de corte machos na fase de 22 a 42 dias de idade. Revista Brasileira de Zootecnia 1999;28:98-104.

Costa FGP, Amarante JVS, Nascimento GAJ, Brandão PAB, Leilane R, Silva JHV, Costa JS. Níveis de lisina para frangos de corte nos períodos de 22 a 42 e de 43 a 49 dias de idade. Ciência e Agrotecnologia 2006;30(4):759-766.

Costa FGP, Rostagno HS, Albino LFT, Gomes PC, Toledo RS. Níveis dietéticos de lisina para frangos de corte de 1 a 21 e 22 a 40 dias de idade. Revista Brasileira de Zootecnia 2001; 30(5):1490-1497.

Goulart CC, Costa FGP, Lima NRC, Souza JG, Silva JHV, Givisiez PEN Exigência de lisina digestível para frangos de corte machos de 1 a 42 dias de idade. Revista Brasileira de Zootecnia 2008;37(5):876-882.

Kerr AK, Farrar AM, Waddell LA, Wilkins W, Wilhelm BJ, Bucher O, Wills RW, Bailey RH, Varga C, McEwen SA, Rajić A. A systematic reviewmeta-analysis and meta-regression on the effect of selected competitive exclusion products on Salmonella spp. prevalence and concentration inbroiler chickens. Preventive Veterinary Medicine. 2013;111(1/2): 112 125.

Kidd M, Fancher BI. Lysine needs of starting chicks and subsequent effect during the growing period. Journal of Applied Poultry Research 2001; 10:385-393

Lana SRV, Oliveira RFM, Donzele JL. Níveis de lisina digestível em rações para frangos de corte de 22 a 42 dias de idade, mantidos em ambiente de termoneutralidade Revista Brasileira de Zootecnia 2005;34:16241632.

Leclercq B. Specific effects of lysine on broiler production: comparison with threonine and valine. Poultry Science 1998; 77:118-123. 
Lovatto PA. Meta-análise em pesquisas científicas: enfoque em metodologias. Revista Brasileira de Zootecnia 2007;36:285-294.

Mateos GG, Mohiti-Asli M, Borda E, Mirzaie S, Frikha M. Effect of inclusion of porcine mucosa hydrolysate in diets varying in lysine content on growth performance and ileal histomorphology of broilers. Animal Feed Science and Technology 2013; 187:53-60.

Moro DN, Zanella I, Figueiredo EAP, Silva JHS. Desempenho produtivo de quatro linhagens de frangos de corte. Ciência Rural 2005;35(2):446449.

Namazu LB, Kobashigawa E, Albuquerque R, Schammass, Eliana A, Takeara PA, Trindade neto MA. Lisina digestível e zinco quelado para frangos de corte machos: desempenho e retenção de nitrogênio na fase préinicial. Revista Brasileira de Zootecnia 2008; 37(9):1634-1640.

Nascimento A. Lisina: principal aminoácido para deposição protéica. AveWorld 2003; 1(1):56-61.

Ojano-Dirain CP, Waldroup PW. Evaluation of lysine, methionine and threonine needs of broilers three to six week of age under moderate temperature stress. International Journal of Poultry Science 2002;1(1):16-21.

Pavan AC, Mendes AA, Oliveira EG. Efeito da linhagem e do nível de lisina da dieta sobre a qualidade da carne do peito de frangos de corte. Revista Brasileira de Zootecnia 2003; 32(6):1732-1736.

Rama SV, Rao MVLN, Raju AK, Panda NS, Poonam OK, Moorthy T, Shyam Sunder G. Performance, carcass variables and immune responses in commercial broiler chicks fed graded concentrations of threonine in diet containing sub-optimal levels of protein. Animal Feed Science and Technology 2011;169(3/4):218-223.

Rodrigues KF, Rodrigues PB, Freitas RTF, Bertechini AG, Albino LFT, Fassani EJ. Relação lisina digestível: proteína bruta em dietas para frangos de corte no período de 1 a 21 dias de idade. Desempenho e metabolismo. Revista Brasileira de Zootecnia 2008; 37(3):450-457.

Rostagno HS, Albino LFT, Donzele JL. Tabelas brasileiras para aves e suínos: composição de alimentos e exigências nutricionais. 2nd ed. Viçosa: Editora UFV; 2005.

Salehifar E, Shivazad M, Foroudi F, Chamani M, Kashani RB. Reevaluation of digestible amino acid requirements of male and female broilers based on different ideal amino acids ratios in starter period. Livestock Science 2012;147(1/3):154-158

SAS Institute. Statistical analysis system introductory guide for personal computers. Release. Cary; 2001.

Sauer N, Emrich K, Piepho HP, Lemme A, Redshaw MS, Mosenthin R. Metaanalysis of the relative efficiency of methionine-hydroxy-analogue-freeacid compared with dl-methionine in broilers using nonlinear mixed models. Poultry Science 2008;87:2023-2031.

Siqueira JC, Oliveira RFM, Donzele JL, Cecon PR, Balbino EM, Oliveira WP. Níveis de lisina digestível da ração e temperatura ambiente para frangos de corte em crescimento. Revista Brasileira de Zootecnia 2007;36(6):2054-2062.

Sklan D, Noy Y. Catabolism and deposition of amino acids in growing chicks: effect of dietary suply. Poultry Science 2004;83:952-961.

Toledo AL, Takaeda P, Kobashigawa E. Níveis dietéticos de lisina digestível para frangos de corte machos no período de 1 a 11 dias de idade: desempenho e composição corporal. Revista Brasileira de Zootecnia 2007;36(4):1090-1096.

Trindade Neto MA, Kobashigawa E, Namazu LB. Lisina digestível e zinco orgânico para frangos de corte machos na fase de 22 a 42 dias de idade. Revista Brasileira de Zootecnia 2010;39:2460-2470.

Trindade Neto MA, Takaeda P, Toledo AL. Níveis de lisina digestível para frangos de corte machos no período de 37 a 49 dias de idade. Revista Brasileira de Zootecnia 2009; 38(3):508-514.

Trindade Neto MA. Dietary levels of lysine for male broilers from 23 to 36 days of age: performance and body composition. Revista Brasileira de Zootecnia 2011;40(3):609-615.

Valério SR, Oliveira RFM, Donzele JL. Níveis de lisina digestível em rações, mantendo ou não a relação aminoacídica, para frangos de corte de 22 a 42 dias de idade, sob condições de estresse por calor. Revista Brasileira de Zootecnia 2003;32(2):372-382.

Van Houwelingen HC, Arends LR, Stijnen T. Advanced methods in metaanalysis: Multivariate approach and meta-regression. Statistics Medicine 2002; 21:589-624. 